\title{
Firestop: a chemical against bacterial diseases of fruit trees recently available in Europe
}

\author{
MN Brisset, J Luisetti, JL Gaignard \\ INRA, Station de Pathologie Végétale et de Phytobactériologie, Rue Georges Morel, 49070 Beaucouzé, France
}

(Received 25 September 1990; accepted 23 November 1990)

\begin{abstract}
Summary - Effectiveness of Firestop, a slow release formulation of flumequine, was evaluated under controlled conditions (greenhouse, controlled environment chamber) and in experimental orchards, against Erwinia amylovora (fire blight) in pear and apple, and Pseudomonas syringae pv persicae (bacterial dieback) in peach. Firestop ( $0.3 \mathrm{~g}$ ai $\mathrm{I}^{-1}$ for fire blight and 0.1 or $0.15 \mathrm{~g}$ ai $t^{-1}$ for bacterial dieback) was as efficient as Bordeaux mixture and less efficient than the conventional antibiotics, streptomycin or oxytetracycline. Firestop exhibits no phytotoxic effects, can be applied during the vegetative period and may be recommended in countries where classical antibiotics are not allowed for control of plant disease.
\end{abstract}

fire blight / Erwinia amylovora / pear / apple / bacterial dieback / Pseudomonas syringae pv persicae / peach

Résumé - Firestop : un produit utilisable en Europe dans la lutte contre les bactérioses des arbres fruitiers. Firestop est une formulation de la fluméquine libérant lentement la matière active. Son efficacité est évaluée en serre et en verger dans le cas du feu bactérien des pommier et poirier (Erwinia amylovora) et du dépérissement bactérien du pêcher (Pseudomonas syringae pv persicae). A 0,3 g.t $\mathrm{t}^{-1}$ pour le feu bactérien et 0,1 ou $0,15 \mathrm{~g} . \mathrm{r}^{-1}$ pour le dépérissement bactérien, il s'est révélé tant en serre (tableaux I et II) qu'en champ (tableaux III et IV) aussi bon que la bouillie bordelaise, mais moins efficace que les antibiotiques streptomycine et oxytétracycline. Aucun effet phytotoxique n'étant induit par Firestop, il peut être recommandé, en particulier dans les pays où les antibiotiques ne sont pas autorisés.

lutte chimique $/$ Erwinia $/$ Pseudomonas $/$ Prunus persica $=$ pêcher $/$ Malus pumila $=$ pommier $/$ Pyrus communis $=$ poirier

\section{INTRODUCTION}

Two major bacterial diseases affect fruit trees in French orchards: fire blight caused by Erwinia amylovora (Burrill) Winslow et al in pear and apple, and bacterial dieback incited by Pseudomonas syringae pv persicae Dye et al (Prunier et al) in peach. Control measures rely upon the use of selected resistant or moderately susceptible cultivars and the application of a number of technical measures, including prophylactic treatment such as chemical sprays. Furthermore, a good knowledge of the epidemiology of each bacterial disease is an essential basis for an effective control. Such knowledge is also needed in designing experiments aimed at finding new chemicals for the control of these diseases. The experimental pro- cedure differs according to the kind of disease to be controlled. We present here results obtained with a single chemical against 2 fruit tree diseases of different types.

$E$ amylovora is generally not epiphytic, except on flowers under certain climatic conditions (Billing and Paulin, 1990). New infections take place mainly during the bloom period. Bacterial inoculum sources include cankers, necrosis and ooze production on infected plants in the vicinity. The success of infection is directly related to local climatic and agronomic factors. Disease severity in different years in the same orchard is, therefore, highly variable. This implies that chemical sprays to control the disease are not systematically needed each year. Nevertheless, the need for an effective chemical is obvious, even if its ap- 
plications are restricted to high-risk periods. These can be predicted with a suitable forecasting system based on some climatic parameters (rain, minimal and maximal temperature) (Billing, 1980; Jacquart-Romon et al, 1987; Van der Zwet et al, 1988; Steiner, 1990).

Conversely, $P s$ pv persicae is a typical epiphyte (Gardan et al, 1972). Previous experiments have demonstrated a close relationship between the amount of bacterial cells present on the leaves during (or just before) leaf fall, and the severity of the disease recorded in spring, of the following year (Gaignard et al, 1976). Chemical sprays are then regularly needed each year to suppress, or at least to drastically reduce, the inoculum level on leaves in autumn.

The number of chemicals available for the control of bacterial diseases is limited. None of them are systemic, and therefore they must always be applied preventively. Antibiotics are the most widely used antibacterial agents in human and animal medicine. Streptomycin and oxytetracycline are registered for phytosanitary use in some countries including the USA, but as a rule they are not allowed in most European countries. This is mainly due to the potential risk of selection of transferable multi-drug resistance plasmids among the pathogenic or saprophytic bacterial populations exposed to antibiotics (Manceau et al, 1987). This potential also represents a threat to human health. Copper compounds are the other conventional antibacterial agents used against bacterial plant diseases. However, under certain conditions, in some plant species, severe burning or other phytotoxic effects may occur (Reil et al, 1973). Their use is consequently limited, although their activity in the case of these 2 diseases is significant (Gaignard et al, 1976; Garrett, 1990).

It is therefore evident that at least in Europe, there is a need for other chemicals for management of bacterial plant diseases. The chemical tested in our experiments, Firestop, lacks the 2 negative side-effects associated with conventional antibiotics and copper compounds. This chemical has recently been registered in France for the control of both fire blight and bacterial dieback, and also in few other European countries as treatment against fire blight (Brisset et al, 1990; Garrett, 1990).

\section{MATERIALS AND METHODS}

\section{Chemicals}

Firestop is the commercial name of a chemical developed by the French branch of the $3 \mathrm{M}$ company (3M Santé). It is a slow release formulation of the antibacterial compound flumequine (6,7-dihydro-9-fluoro-5methyl-1-oxo-1H, 5H-benzo [i,j] quinolizine-2carboxylic acid). Flumequine, a synthetic antibiotic belonging to the quinolone group, is used in medical practice. No plasmid resistance to this compound is known (this is probably related to its site of action, which is DNA gyrase). It is not a systemic chemical and acts only as a prophylactic. The interest of flumequine (MBR 10995) in fire blight control was first demonstrated in California (Thomson et al, 1976).

Different chemical agents were used as standard of effectiveness in our experiments: 1), streptomycin was used as a standard for the fire blight experiments. The formulation used was Plantomycin $(17.76 \%$ streptomycin sulphate) from ICl Bayer, Rotterdam; 2), oxytetracycline was used as a standard for dieback in the peach experiments. The formulation used was Mycoshield (17\% oxytetracycline) from Pfizer, NYork; 3 ), copper sulphate is the routinely recommended chemical for use against fire blight and bacterial dieback; the formulation we used was "Bouillie Bordelaise" $(20 \%$ active $\mathrm{Cu}$ ) from RSR $\mathrm{Co}$, Marseille, France.

\section{Fire blight experiments}

Artificial inoculations were performed with aqueous bacterial suspensions (containing $5 \times 10^{8}$ and $10^{9}$ cells $/ \mathrm{ml}$ of sterile distilled water, for greenhouse and field experiments respectively) of the virulent strain of E amylovora CFBP 1430, obtained from a 24-h culture at $26^{\circ} \mathrm{C}$ on King's medium B (King et al, 1954).

In the greenhouse, seedlings from open-pollinated trees of the pear cv Passe Crassane and of the apple cv Golden Delicious were used at the 8-10-leaf stage. The 2 youngest leaves of each seedling ( 3 replicates of 20 seedlings per treatment and per $\mathrm{cv}$ ) were wounded by cutting with a scalpel accross the mid-vein. Chemicals, ie Firestop $\left(0.3 \mathrm{~g}\right.$ ai $\left.\left.\right|^{-1}\right)$, Plantomycin $(0.1$ $\mathrm{g}$ ai $\left.\left.\right|^{-1}\right)$, and a water control, were sprayed to run-off. Plants were then allowed to dry for $3 \mathrm{~h}$. Finally, a bacterial suspension of $E$ amylovora was sprayed to run off on the leaves. The number of infected seedlings, ie showing a progressive necrosis from the wound on the mid-vein, was assessed $12 \mathrm{~d}$ after inoculation.

In the field, experiments were performed on adult trees in the Dax experimental orchard situated in the south-west of France and devoted to fire blight re- 
search under EEC and Ministère de l'Agriculture (France) support. Golden Delicious apple and Pierre Corneille pear were selected as test-cultivars, because of a relatively high blossom receptivity associated with a low shoot susceptibility (Le Lezec et al, 1986). These features resulted in a high frequency of infection following flower inoculation, but only in a limited subsequent progression of the bacteria into the shoots. As a result, the framework of the tree escaped destruction, even after several years of repeated infection. A previously described blossom inoculation method (Kooistra and Langeslag, 1981) was followed. Chemicals, ie Firestop $\left(0.3\right.$ and $0.1 \mathrm{~g}$ ai $\left.I^{-1}\right)$, Plantomycin $\left(0.1 \mathrm{~g}\right.$ ai $\left.\left.\right|^{-1}\right)$, Bouillie Bordelaise $\left(1 \mathrm{~g}\right.$ ai $\left.\left.\right|^{-1}\right)$, and a water control were first applied to carefully selected blossoms, at or near full bloom (4 replicates of 50 blossoms per treatment and per $\mathrm{cv}$ ). They were allowed to dry for 1 to several $h$ (depending on the weather). A bacterial suspension of $E$ amylovora was then sprayed to run-off on the blossoms. The number of blighted blossoms was assessed within 3 wk of inoculation. One-way analyses of variance were performed after suitable transformation of the data allowing the classification of means according to Duncan's multirange test.

\section{Bacterial dieback}

Plants were inoculated with aqueous bacterial suspensions ( $10^{8}$ cells per $\mathrm{ml}$ of sterile distilled water) of the streptomycin-resistant strain INRA M24S of $P s$ pv persicae, obtained from a $3-\mathrm{d}$ culture at $20-22^{\circ} \mathrm{C}$ in a fermentor in LPG (Prunier et al, 1970).

Peach seedlings (2-yr old) from seeds of the cultivar GF 305 (11 per treatment) were sprayed to run-off with the bacterial suspension of $P s$ pv persicae and kept in a controlled environment chamber $\left(20{ }^{\circ} \mathrm{C}\right.$, between $65-90 \% \mathrm{RH}$ ) for $5-6 \mathrm{~d}$ to favour colonization of the leaf surface by the pathogen. Chemicals, ie Firestop

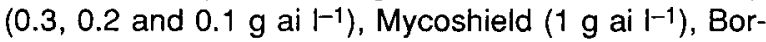

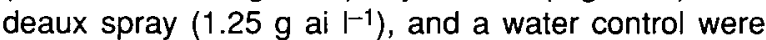
then applied by spraying. Just before application of the chemicals, leaves were sampled to monitor the level of $P s$ pv persicae population on the leaf surface. Such samplings were performed at 1, 2, 4, 8, 11 and finally $15 \mathrm{~d}$ after spraying. Each sample of 50 leaves selected randomly from the seedlings corresponding to each treatment was homogenized in a Warring blender with $500 \mathrm{ml}$ sterile distilled water. The resulting suspension and its 4 first 10 -fold dilutions were spread on plates containing a suitable medium (LPGA $+0.05 \mu \mathrm{g} \cdot \mathrm{ml}^{-1}$ streptomycin) and were incubated for $3 \mathrm{~d}$ at $23^{\circ} \mathrm{C}(5$ replicates per dilution). The population level was expressed as the logarithm of the number of $P s \mathrm{pv}$ persicae cells per leaf.

In an experimental orchard located in the area where the disease is endemic (Valence, south-east of France), 50 trees (3-yr old cv Redwing/GF 305) were selected randomly and were sprayed with the bacterial suspension of $P s$ pv persicae twice just at the beginning of leaf fall. From the 7 th $d$ after the 2 nd bacterial spraying and every $10 \mathrm{~d}$ until the end of leaf fall, chemicals, ie Firestop $\left(0.3\right.$ and $0.15 \mathrm{~g}$ ai $\left.\left.\right|^{-1}\right)$, Mycoshield ( $1 \mathrm{~g}$ ai $\left.\left.\right|^{-1}\right)$, Bordeaux spray $\left(1.25 \mathrm{~g}\right.$ ai $\left.\left.\right|^{-1}\right)$, and a water control were applied ( 10 trees per treatment). Just before and $4 \mathrm{~d}$ after each spraying and $10 \mathrm{~d}$ after the last treatment, 60 leaves were randomly collected from the 10 trees corresponding to each treatment for counting of bacterial populations. The same procedure as above was followed for plating and incubation. Four months later in March, an assessment of the necroses which had appeared around dormant buds during winter was performed.

A statisical analysis using a non-parametric test based on the sum of the ranks of each treatment according to population levels recorded at each date (Kramer's test) was applied.

\section{RESULTS}

\section{Fire blight experiments}

Infection levels obtained in the water control were very high in the greenhouse (ca $84 \%$ of the infected seedlings) and high enough in the field (ca $50 \%$ of the blighted blossoms), showing that inoculations were successful (tables I and II). On the other hand, treatment with the streptomycin standard significantly reduced levels of infection in each experiment, indicating that the experimental methods were adequate for expressing the prophylactic effect of a chemical agent against fire blight.

In the greenhouse (table I), Firestop ( $0.3 \mathrm{~g}$ ai $\left.1^{-1}\right)$ was as effective as Plantomycin in reducing infection of pear seedlings by $E$ amylovora, but less effective on apple seedlings. The percentage of infected apple seedlings treated with

Table I. Efficacy of Firestop on fire blight control on apple and pear seedlings in the greenhouse*.

\begin{tabular}{lccc}
\hline & \multicolumn{3}{c}{$\%$ infected seedlings } \\
& Water & Plantomycin & Firestop \\
Seedlings & control & $0.1^{\star *}$ & 0.3 \\
& & & \\
\hline & & & \\
Pear & $80 \mathrm{a}^{\star \star \star}$ & $30 \mathrm{~b}$ & $28 \mathrm{~b}$ \\
Apple & $88 \mathrm{a}$ & $20 \mathrm{c}$ & $45 \mathrm{~b}$ \\
\hline
\end{tabular}

* Seedlings were first wounded then sprayed to run-off with chemicals and allowed to dry. Inoculation was performed $3 \mathrm{~h}$ later by spraying a bacterial suspension of $E$ amylovora $(5 \times$ $10^{8}$ cells $\left./ \mathrm{ml}\right) .^{* \star} \mathrm{g}$ ai $\left.\right|^{-1}$. ${ }^{\star \star \star}$ Values on the same line followed by the same letter are not significantly different $(P=0.05)$ according to Duncan's multiple range test. 
Table II. Efficacy of Firestop on fire blight control on apple and pear trees in the field*.

\begin{tabular}{|c|c|c|c|c|c|}
\hline \multirow[b]{2}{*}{ Cultivars } & \multicolumn{4}{|c|}{$\%$ blighted blossoms } & \multirow[b]{2}{*}{$\begin{array}{c}\text { Firestop } \\
0.1\end{array}$} \\
\hline & $\begin{array}{l}\text { Water } \\
\text { control }\end{array}$ & $\underset{1}{\text { Bordeaux }}$ & $\begin{array}{c}\text { Plantomycin } \\
0.1\end{array}$ & $\begin{array}{c}\text { Firestop } \\
\quad 0.3\end{array}$ & \\
\hline Pierre Corneille & $44 \mathrm{a}^{\star \star \star}$ & $28 a b$ & $10 \mathrm{~b}$ & $18 a b$ & $43 a$ \\
\hline Golden Delicious & $57 \mathrm{a}$ & $12 \mathrm{~b}$ & $3 c$ & $12 b$ & $12 b$ \\
\hline
\end{tabular}

"Blossoms were sprayed with chemicals to run-off and allowed to dry. Inoculation was performed several h later by spraying a bacterial suspension of $E$ amylovora $\left(10^{9} \mathrm{cells} / \mathrm{ml}\right) .{ }^{* *} \mathrm{~g}$ ai $t^{-1} .{ }^{* * *}$ Values on the same line followed by the same letter are not significantly different $(P=0.05)$ according to Duncan's multiple range test.

this chemical was intermediate between those obtained with Plantomycin and water control. On pear and apple trees in the field (table II), effectiveness of Firestop at $0.3 \mathrm{~g}$ ai $1^{-1}$ was similar to that of Bouillie Bordelaise. On apple, levels of infection obtained with these 2 chemicals were significantly lower than those obtained with the water control and significantly higher than those obtained with Plantomycin. On pear the trends were the same although the differences, either with the control or with the streptomycin standard, were not significant. Only the latter resulted in drastically reduced levels of infection. At $0.1 \mathrm{~g}$ ai $l^{-1}$, Firestop did not protect pear from $E$ amylovora infection, while on apple this low dosage was as effective as $0.3 \mathrm{~g}$ ai $\mathrm{I}^{-1}$.

\section{Bacterial dieback experiments}

In controlled environment chamber (table III), the log of population level for the water control remained around 5.00. For the oxytetracycline standard, the bacterial inoculum was undetectable on leaves after $4 \mathrm{~d}$. For the copper sulphate standard the population dropped to a low level immediately after the spray, then increased to $10^{5}-10^{6}$ cells per leaf on the 11 th $\mathrm{d}$. No bacteria were recovered on the last day. For the Firestoptreated trees, the population decreased within the first $2 \mathrm{~d}$, whatever the dosage of the chemical. Although it increased again either between the 2nd and the 4th dor between the 4th and the 8th $d$, the population remained at a lower level

Table III. Effect of Firestop on $P s$ pv persicae populations on peach seedlings in controlled environment chamber*.

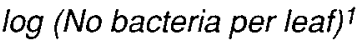

\begin{tabular}{rcccccc}
$\begin{array}{c}\text { Days after } \\
\text { chemical } \\
\text { treatments }\end{array}$ & $\begin{array}{c}\text { Water } \\
\text { control }\end{array}$ & $\begin{array}{c}\text { Mycoshield } \\
1^{\star * *}\end{array}$ & $\begin{array}{c}\text { Bordeaux } \\
1.25\end{array}$ & $\begin{array}{c}\text { Firestop } \\
0.1\end{array}$ & $\begin{array}{c}\text { Firestop } \\
0.2\end{array}$ & $\begin{array}{c}\text { Firestop } \\
0.3\end{array}$ \\
\hline & & & & & & 5.30 \\
0 & 4.70 & 5.60 & 5.00 & 5.65 & 5.55 & 5.20 \\
1 & 4.10 & 2.30 & 2.20 & 3.50 & 3.65 & 4.10 \\
2 & 4.80 & 0.00 & 5.80 & 4.10 & 4.10 & 5.25 \\
4 & 6.20 & 4.90 & 4.60 & 3.80 & 5.40 & 4.40 \\
8 & 4.50 & $0.00^{1}$ & 6.60 & 4.70 & 3.90 & 3.74 \\
11 & 5.38 & 0.00 & 5.24 & 4.65 & 3.14 & 3.15
\end{tabular}

\footnotetext{
1 The limit of detection level expressed as a logarithm is 1.70 . ${ }^{*}$ Seedlings were sprayed to run-off with a bacterial suspension of $P S$ pv persicae $\left(10^{8} \mathrm{cells} / \mathrm{ml}\right)$. A few days later, chemicals were applied by spraying. ${ }^{\star \star}$ Leaves were sampled to monitor the number of $P$ $s$ pv persicae on leaf surface, just before chemical treatments $(\mathrm{d} 0)$ and $1-15 \mathrm{~d}$ after. ${ }^{* \star *} \mathrm{~g}$ ai $\mathrm{I}^{-1}$.
} 
than in the water control. There were no differences between the 3 concentrations, but the populations on the trees sprayed with the 2 lowest concentrations were consistently lower than those on trees sprayed with the highest concentration. According to the Kramer's test, the ranks of the Firestop-treated tree populations were significantly higher than those of the water control and no significant differences were found between the 3 concentrations of the drug.

In the field (table IV), initial populations were quite high (log of populations between 5.556.67). The log of the number of $P s \mathrm{pv}$ persicae on the water-treated trees remained at a level fluctuating between 6.34-4.70. The bacterial population on the trees sprayed with Mycoshield decreased regularly and seemed to be completely eliminated during the last days of the leaf fall. The bacterial populations on the trees treated either with the Bordeaux mixture or with Firestop (all concentrations) decreased slowly but remained at a level $>10^{4}$ cells per leaf. The Kramer's test showed that the ranks of the populations corresponding to the Bordeaux mixture and Firestop-treated trees were significantly higher than those of the water control and significantly lower than those of oxytetracycline-sprayed trees. Unfortunatly the climatic conditions in the following winter did not favour the development of infections on the twigs and only one necrotic reaction was recorded in spring and no comparisons between the number of necroses obtained in each plot were allowed.

\section{DISCUSSION}

Fire blight and bacterial dieback are 2 diseases which differ widely in their epidemiology. This requires different experimental approaches in research on chemical control. For fire blight, natural infections of blossoms or shoots must be simulated. Of particular importance is the fact that the date of infection (ie time of inoculation) must be known and the date of chemical spraying was chosen in relation to this precise infection date. This is obviously not the case in natural conditions, and important parameters such as the stability of the activity of the chemical on the plant, or the length of the effectiveness period, which play a key role under these conditions, could not be taken into account in our experiments. For bacterial dieback, the experiments were essentially based on the comparison of the effects of chemicals on the epiphytic populations that were artificially established on the leaves a

Table IV. Effect of Firestop on $P s$ pv persicae populations on peach trees in the field*.

$\log (\text { No bacteria per leaf })^{1}$

\begin{tabular}{|c|c|c|c|c|c|}
\hline $\begin{array}{c}\text { Calendar } \\
\text { of leaf } \\
\text { sampling }\end{array}$ & $\begin{array}{l}\text { Water } \\
\text { control }\end{array}$ & $\underset{f^{* * *}}{\text { Mycoshield }}$ & $\begin{array}{c}\text { Bordeaux } \\
1.25\end{array}$ & $\begin{array}{c}\text { Firestop } \\
0.3\end{array}$ & $\begin{array}{c}\text { Firestop } \\
0.15\end{array}$ \\
\hline Before $T_{1}$ & 5.77 & 6.05 & 5.55 & 6.67 & 6.01 \\
\hline $4 \mathrm{~d}$ after $T_{1}$ & 6.05 & 4.72 & 5.97 & 5.70 & 6.31 \\
\hline Before $T_{2}$ & 6.34 & 5.34 & 5.84 & 6.57 & 5.92 \\
\hline $4 \mathrm{~d}$ after $T_{2}$ & 5.24 & 4.49 & 5.07 & 5.60 & 5.23 \\
\hline Before $T_{3}$ & 5.79 & 3.88 & 5.20 & 5.93 & 5.68 \\
\hline $4 \mathrm{~d}$ after $T_{3}$ & 5.26 & 3.51 & 5.45 & 5.45 & 5.37 \\
\hline Before $T_{4}$ & 4.81 & 4.40 & 4.52 & 5.68 & 3.96 \\
\hline $4 \mathrm{~d}$ after $\mathrm{T}_{4}$ & 5.27 & $0.00^{1}$ & 3.95 & 5.08 & 4.62 \\
\hline $10 \mathrm{~d}$ after $\mathrm{T}_{4}$ & 4.70 & & 3.40 & 4.22 & 4.00 \\
\hline
\end{tabular}

\footnotetext{
1 The limit of detection level expressed as a logarithm is $1.70 .{ }^{*}$ Trees were inoculated twice during the first stage of the leaf fall by spraying a bacterial suspension of $P s$ pv persicae $\left(10^{8}\right.$ cells per $\left.\mathrm{ml}\right)$. Four treatments of chemicals were performed: the 7 th $\mathrm{d}$ after the 2nd inoculation $\left(T_{1}\right)$ and every $10 \mathrm{~d}$ until the end of the leaf fall $\left(\mathrm{T}_{2}, \mathrm{~T}_{3}, \mathrm{~T}_{4}\right)$. ${ }^{\star \star *}$ Leaves were sampled to monitor the number of $P$ $s \mathrm{pv}$ persicae on the leaf surface, just before and $4 \mathrm{~d}$ after each chemical treatment. ${ }^{* *} \mathrm{~g}$ ai $\mathrm{l}^{-1}$.
} 
few days before the chemicals were applied. Many experiments have confirmed the reliability of such a procedure (Gaignard et al, 1976; Luisetti et al, 1976). Whatever the disease, effectiveness of chemical agents shown in controlled conditions (greenhouse or controlled environment chamber) has been confirmed in field experiments. Such tests can be then used for a preliminary screening of chemicals against these diseases.

The relative effectiveness of the chemical tested, as compared to standards in the protection of apple and pear against fire blight and against dieback in peach can be determined from these results. Against fire blight Firestop $\left(0.3 \mathrm{~g}\right.$ ai $\left.\mathrm{I}^{-1}\right)$ was found to be as effective in the field as Bordeaux spray $\left(1 \mathrm{~g}\right.$ ai $\left.~^{-1}\right)$. However, it was less efficient than Plantomycin $\left(0.1 \mathrm{~g}\right.$ a $\left.\mathrm{I}^{-1}\right)$. In reducing populations of $P s \mathrm{pv}$ persicae on peaches, Firestop $\left(0.1-0.3 \mathrm{~g}\right.$ ai $\left.\mathrm{I}^{-1}\right)$ was equivalent to the Bordeaux mixture $\left(1.25 \mathrm{~g}\right.$ ai $\left.~^{-1}\right)$, but significantly less effective than Mycoshield used at a high concentration ( $\mathrm{g}$ ai $\left.\left.\right|^{-1}\right)$. Finally, it should be noted that no phytotoxicity was recorded on flowers or any other parts of trees or seedlings sprayed with Firestop on pear, apple or peach, while some phytoxicity is usually associated with the use of copper compounds on these plants.

\section{CONCLUSION}

According to our results, Firestop is likely to be useful in spraying against fire blight and bacterial dieback. Firestop (flumequine) is active against numerous Gram-negative bacteria (Manceau et al, 1987) and could be tested against other bacterial diseases. Firestop can act only as preventive chemical agent. In other experiments, which have not been reported here, we have shown that there is no antibacterial activity after bacteria are established in the plant tissues: it is best used, particularly for fire blight control, in connection with a suitable disease forecasting system which enables spraying to be carried out before an outbreak of infection.

Firestop has the additional advantage of not being a completely new chemical: it is already in use in other areas against other pathogens, and at least part of the required background information needed for public release (human toxicity, etc), is already available. The specific risk of transferable multi-drug resistance, which is of great concern for the registration of a new anti- bacterial compound, seems to be avoided with this chemical.

\section{ACKNOWLEDGMENTS}

We acknowledge the advice of JP Paulin throughout these studies and the helpful criticisms in the preparation of this manuscript. We are grateful to ED Civerolo for critical reading of the paper. We also wish to thank $R$ Chartier, G Lachaud and M Devaux for technical assitance. MN Brisset was holder of a fellowship from $3 \mathrm{M}$ Santé and the ministère de la Recherche et de la Technologie CIFRE (France).

\section{REFERENCES}

Billing E (1980) Fire blight (Erwinia amylovora) and weather: a comparison of warning systems. Ann App/ Biol 95, 365-377

Billing E, Paulin JP (1990) Field observations and epidemiological studies in relation to risk assessment. In: Le Feu Bactérien des Pomoïdeae. CECA-EECCEA, Brussels, 34-37

Brisset MN, Chartier R, Paulin JP, Chevalier R (1990) Experimentations with Firestop $3 \mathrm{M}$ in the chemical control of fire blight. Acta Hortic 273, 413-418

Gaignard JL, Gardan L, Luisetti J, Prunier JP, Minodier R (1976) La lutte chimique contre Pseudomonas persicae, agent du dépérissement bactérien du pêcher. Arboric Fruit 271, 21-26

Gardan L, Prunier JP, Luisetti J (1972) Études sur les bactérioses des arbres fruitiers. IV. Recherche et étude des variations de Ps mors-prunorum f sp persicae à la surface des feuilles de Pêcher. Ann Phytopathol 4, 229-244

Garrett CME (1990) Control of fire blight. In: Fire Blight of Pomoïdeae, Applied Research in Europe (19781988). CECA-EEC-CEA Brussels, 54-78

Jacquart-Romon C, Paulin JP, Payen D (1987) A computer program based on Billing's system 1 for timing of control measures against fire blight. Acta Hortic $217,119-123$

King EO, Ward MK, Raney DE (1954) Two simple media for the demonstration of pyocyanin and fluores cin. J Lab Clin Med 44, 301-307

Kooistra T, Langeslag JJ (1981) Experiences with chemicals against Erwinia amylovora. Acta Hortic 117, 97-106

Le Lezec M, Babin J, Lecomte P (1986) Sensibilité de pommes américaines et européennes au feu bactérien. Arboric Fruit 388, 23-31

Luisetti J, Prunier JP, Gardan L, Gaignard JL, Vigouroux A (1976) Le Dépérissement Bactérien du Pêcher. INVUFLEC, Paris, pp 60 
Manceau C, Gardan L, Paulin JP (1987) Use of antibiotics to control fire blight in France: environmental hazards and established legislation. Acta Hortic 217, 195-202

Prunier JP, Luisetti J, Gardan L (1970) Études sur les bactérioses des arbres fruitiers. II. Caractérisation d'un Pseudomonas non-fluorescent agent d'une bactériose nouvelle du pêcher. Ann Phytopathol 2, I, 181-197

Reil WO, Beutel JA, Moller WJ (1973) Fire blighteffects of control sprays on russeting of Barlett pears. Calif Agric 27, 6, 5-6
Steiner PW (1990) Predicting apple blossom infections by Erwinia amylovora using the Maryblit model. Acta Hortic 273, 139-148

Thomson SV, Schroth MN, Moller WJ, Reil W (1976) Efficacy of bactericides and saprophytic bacteria in reducing colonization and infection of pear flowers by Erwinia amylovora. Phytopathology 66, 1457 1459

Van der Zwet T, Zoller BG, Thomson SV (1988) Controlling fire blight of pear and apple by accurate prediction of the blossom light phase. Plant Dis Rep 72 (6), $462-474$ 